\title{
An entrepreneurial career impacts on job and family satisfaction
}

\author{
Luciana Padovez-Cualheta \\ Universidade de Brasilia, Brasilia, Brazil \\ Candido Borges \\ Universidade Federal de Goias, Goiania, Brazil, and \\ Altair Camargo and Lucas Tavares \\ Universidade de Sao Paulo, Sao Paulo, Brazil
}

\begin{abstract}
Purpose - This paper aims to identify if entrepreneurship as a career option is related to job satisfaction and family satisfaction by comparing entrepreneurs with non-entrepreneurs. To do so, a tool was used to measure job satisfaction, family satisfaction and the existence of interrole conflicts.

Design/methodology/approach - Cluster analysis and linear regression models were used to test the hypotheses.

Findings - Results indicate that there is a positive relationship and that entrepreneurs have higher rates of job satisfaction than non-entrepreneurs. Contrary to what the literature suggests, this study found that entrepreneurs have a higher rate of family satisfaction than non-entrepreneurs, and that there is no difference between men's and women's levels of satisfaction.

Research limitations/implications - Among the limitations of the research, the authors cite the fact that there was no randomness in the designation of the respondents and the fact that the answers were obtained by self-report. Also, the research was cross-sectional, making it impossible to compare answers between the same individuals at different points of time.

Practical implications - Results can help individuals decide whether to start a business and to assist development agencies in the creation of incentive policies.

Originality/value - As an academic implication, results contribute to the literature on this topic by relating entrepreneurship with the quality of life and not only with financial variables. Yet, it is one of the first studies on this topic in Brazil.
\end{abstract}

Keywords Entrepreneurship, Job satisfaction, Family satisfaction, Interrole conflicts, Entrepreneurial career

Paper type Research paper

\section{Introduction}

Literature shows that entrepreneurship can positively affect society in terms of job creation, national economic growth (Carree \& Thurik, 2010) and increases in family income

(C) Luciana Padovez-Cualheta, Candido Borges, Altair Camargo and Lucas Tavares. Published in RAUSP Management Journal. Published by Emerald Publishing Limited. This article is published under the Creative Commons Attribution (CC BY 4.0) licence. Anyone may reproduce, distribute, translate and create derivative works of this article (for both commercial and non-commercial purposes), subject to full attribution to the original publication and authors. The full terms of this licence may be seen at http://creativecommons.org/licences/by/4.0/legalcode 
RAUSP

54,2

(Summers, 2015), but does not present conclusive results when analyzing how the option for entrepreneurship impacts an entrepreneur's quality of life in aspects other than family income (Dolan, Peasgood, \& White, 2008). In the pursuit of a better quality of life, can entrepreneurship be considered a good career choice? This is an issue faced by many individuals when they consider the possibility of starting up their own businesses or working for an already existing company.

Certain characteristics of entrepreneurship can negatively influence the entrepreneur's quality of life. In general, entrepreneurship is associated with risk, uncertainty regarding business success and higher levels of autonomy and responsibility - issues that can generate negative feelings, such as loneliness (Patzel \& Shepherd, 2011). It can also cause conflicts between work and family, due to indefinite working hours, reduction in the number of hours available for family and difficulties in talking about work activities with the family - all of which can lead to tension and tension in family relations (Strobino \& Teixeira, 2014).

Entrepreneurs experience higher levels of stress than non-entrepreneurs, as nascent entrepreneurs put in long working hours, because of the financial impossibility of hiring employees or in their efforts to increase earnings (Cardon \& Patel, 2015). In this context, the difficulties of creating and managing one's own company can cause physical and emotional problems for entrepreneurs, thereby reducing their quality of life (Morris \& Lewis, 1991). These considerations could lead to the conclusion that entrepreneurship is not a good option regarding quality of life.

However, other studies show the opposite. Research by Binder and Coad (2013); Bradley and Roberts (2004), and Van Praag and Versloot (2007) has found that entrepreneurs are more satisfied with their job than other workers. This shows that when the impacts of entrepreneurship as a work type on an individual's quality of life is analysed in the literature, the evidence is scarce and results are inconclusive, so there is a need to intensify research on the subject (Dolan et al., 2008). It is not conclusively known whether individuals who create their own businesses are more or less satisfied with their quality of life than those who are employed by a company.

Against that background, this article set out to identify if there is a relationship between entrepreneurship as a career option and job satisfaction and family satisfaction, by comparing entrepreneurs with non-entrepreneurs to answer the following research question:

\section{RQ1. Does entrepreneurship as a career choice influence job and family satisfaction?}

The option to analyze job and family satisfaction was based on studies by Rice, Frone, and McFarlin (1992); Near, Smith, Rice and Hunt (1984), who demonstrated that job and family satisfaction are central metrics of a person's perceived quality of life. Satisfaction with work and family, in turn, is measured by the existence or otherwise of interrole conflicts (Rice et al., 1992).

In this article, as in a study by Van Praag and Versloot (2007), entrepreneurs have been defined in operational terms as those who own their own businesses, while those who do not have been defined as non-entrepreneurs. Quality of life was measured using three tools consolidated in the literature, which assess job satisfaction; family satisfaction; and the existence of an interrole conflict. Demographic variables (working hours, number of employees, activity sector, marital status, the presence of children, year of birth, schooling and income) were included, thereby allowing for a better comparison between the groups.

To meet the proposed goal, a questionnaire was drafted based on three consolidated scales in the literature, which measure job satisfaction, family satisfaction and the existence of an interrole conflict. There were 156 respondents, of whom 55 were excluded because 
their questionnaires were incomplete, which left 101 valid answers. Group analysis techniques and linear regression models were used to test the hypotheses.

This article is composed of five sections: Introduction (Section 1), Theoretical foundation (Section 2), Methods (Section 3), Presentation of results (Section 4), a Discussion of the results (Section 5) and Conclusion (Section 6).

\section{Theoretical foundation}

\subsection{Entrepreneurship}

In the literature, there are various definitions of entrepreneurship. Gartner (1989) believes that entrepreneurship is the ability and willingness of individuals, alone or in teams, to perceive and open up new opportunities, by creating and placing new products on the market, new forms of production, new methods of organization and new combinations of product and market. Shane and Venkataraman (2000), in turn, consider entrepreneurship as the process of discovering, evaluating and exploiting opportunities by individuals.

Although certain authors consider that entrepreneurship is a behavioral trait of individuals which means that they cannot, therefore, be classified as a single occupational class (Carree \& Thurik, 2010), many others see it as a career option that can be influenced by various factors such as, having parents who were entrepreneurs (Burton, Sørensen, \& Dobrev, 2016; Mohamad, Lim, Yusof, Kassim, \& Abdullah, 2014), the psychological characteristics of individuals (Callanan \& Zimmerman, 2016; Henderson \& Robertson, 1999), the economic and social milieu (Douglas \& Shepherd, 2002), positive and negative environmental factors (Callanan \& Zimmerman, 2016) and the desire to maximize the use of their career choice (Henderson \& Robertson, 1999). Entrepreneurship can also be inspired by successful entrepreneurs who are constantly in the media (Burton et al., 2016).

Although there is evidence of the benefits of entrepreneurship for economic and societal development factors (Van Praag \& Versloot, 2007), the impacts of its choice as a career option on the quality of life and well-being of entrepreneurs are still inconclusive (Dolan et al., 2008). Much of the research that measures the career success of entrepreneurs only considers financial aspects, such as profit, sales and the number of employees. However, as Nguyen and Sawang (2016) state in their review of the literature, financial success is not the only desire of those who opt for it and become owners of small businesses; for many, having a good quality family life and work is also an indicator of success.

\subsection{Job satisfaction}

Work is a central dimension of satisfaction in the lives of individuals, given the amount of time and energy invested in it and its importance for generating positive social relationships, commanding respect in society and forging a sense of belonging and identity. In addition, the relationship between job and life satisfaction is positive, especially among self-employed workers (Loewe, Araya-Castillo, Thieme, \& Batista-Foguet, 2015).

Binder and Coad (2013); Bradley and Roberts (2004) and Van Praag and Versloot (2007) found that entrepreneurs are more satisfied with their jobs than non-entrepreneurs, even if they work longer hours and earn less. Entrepreneur's greater job satisfaction is probably due to their greater autonomy, flexibility and independence, brought about by the fact that they are responsible for dictating company rules (Millan, Hessels, Thurik, \& Aguado, 2013).

In this same sense, Schneck (2014) researched data from the European Social Survey (ESS) and found that the self-employed are more satisfied than employees because they have greater autonomy in decision-making and more freedom to be creative in their businesses.

Lange (2012) researched aspects of personality and their relationship with the job satisfaction of entrepreneurs and found that even when using control variables, such 
RAUSP

54,2

as job characteristics, sociodemographic characteristics, a person's values and personality traits, entrepreneurs are still more satisfied with their work than nonentrepreneurs.

Zwan, Hessels, and Rietveld (2018) also reported that an individual's career transition from being an employee to being an entrepreneur is directly related to job satisfaction, and that individuals make this career change to increase their satisfaction. The results presented in their study show that job satisfaction really increases and only begins to fall five years after their switch to an entrepreneurial career.

When entrepreneurs, for whatever reason, return to being employees, there is a permanent negative impact on their job satisfaction because, although satisfaction with job security and hours worked increases, their satisfaction with the nature of the job is lower (Georgellis \& Yusuf, 2016).

Thus, $H 1$ is proposed:

H1. Entrepreneurs have a higher job satisfaction rate than non-entrepreneurs.

Hamilton (2000) compared the income satisfaction of entrepreneurs and non-entrepreneurs. His results show that entrepreneurs earn less initially, and that over a 10-year period, their earnings can be to 35 per cent lower than those of non-entrepreneurs. This difference could be even greater if indirect income, such as health insurance and other benefits were considered. He argues that despite their lower income, entrepreneurs' satisfaction rates are higher because of non-pecuniary factors, such as the satisfaction of being owners of their own businesses.

Entrepreneurs who started their businesses out of necessity could feel more satisfied simply because they are in a better financial situation now than previously when perhaps they were unemployed or had jobs which paid less than they now earn owning their own businesses (Millan et al., 2013). Thurairajah (2013), on the other hand, found that employee's satisfaction with their career increases as their wage levels increase. Sáiz-Álvarez, Corduras Martínez, and Cuervo-Arango Martínez (2014) showed that income satisfaction is higher for entrepreneurs at the early stages of their businesses and tends to fall over time, as their incomes become variable and unpredictable (Carter, 2011).

Millan et al. (2013) found similar results for entrepreneurs and non-entrepreneurs, and that income satisfaction is directly related to job satisfaction for both groups. Guerra and Patuelli (2016) showed that job satisfaction could underlie an individual's decision to leave their employment and become an entrepreneur. Those people who choose entrepreneurship at the expense of a fixed job usually do so because of low financial satisfaction with their current employment, even if their non-pecuniary satisfaction is higher. Like entrepreneurs, those who switch from one fixed job to another are often dissatisfied with their income from work. Income seems to be a source of dissatisfaction for both groups.

Therefore, $H 2 a$ and $H 2 b$ are proposed:

H2a. For entrepreneurs, the job satisfaction rate varies according to income.

$H 2 b$. For non-entrepreneurs, the job satisfaction rate varies according to income.

\subsection{Family satisfaction and interrole conflict}

Family well-being indicates a person's degree of satisfaction with their family of origin. A study in this field allows one to identify the feelings and attitudes coming from each type of family structure which, in turn, influences the formation of an individual's personality (Carver \& Jones, 1992). 
Time given to family is influenced by parenting demands and the level of support provided by the partner. Female entrepreneurs usually devote more time to family than men (Parasuraman, Purohit, DGodshalk, \& Beutell, 1996). The level of commitment to family increases the degree of satisfaction in this relationship (Perrone, Aegisdottir, Webb, \& Blalock, 2006). Therefore, the more time spent working, the lower the satisfaction with family.

In addition to assessing job and family satisfaction, studies also examine the conflicts caused by the work-family relationship (Powell \& Eddleston, 2013; Thurairajah, 2013; Zhao, $\mathrm{Qu}, \&$ Ghiselli, 2011). This conflict, called interrole conflict, occurs when the pressures generated by one role are incompatible with those generated by the other (Greenhaus \& Beutell, 1985). Normally, the more time spent on one role, the less there is available to devote to the other. Work-family and family-work conflicts are directly related to stress and thereby reduce an individual's quality of life (Morris \& Lewis, 1991; Parasuraman et al., 1996). Entrepreneurs, in general, usually devote more time to work than non-entrepreneurs (Powell \& Eddleston, 2013).

Conflict can be based on time, effort and behavior. Time-based conflicts are related to the work schedule, flexibility and availability of schedules, marital status, whether there are children and whether the spouse works. Effort-related conflicts usually have the same causes as behavior-based conflicts; they are related to the expected behavior of the individual in each of the roles. A person can be expected to be objective, efficient and hardworking in the job and is expected to be loving and patient at home. Conflict begins when an individual does not meet these expectations (Greenhaus \& Beutell, 1985).

Strobino and Teixeira (2014) researched work-family conflict with entrepreneurs in the construction sector and showed that the time dimension involved conflicts related to undefined working hours, little time given to family, difficulties in talking about work with the family and lack of marital support. The tension dimension incorporates problems arising from financial difficulties in the company or from the need to exact payment from customers for services rendered and also the emotional wear and tear caused by family quarrels. Finally, in the behavioral dimension, the authors found a lack of enthusiasm and motivation for administering a company and bad feelings within the family relationship. In this same context, the study by Nassif, Andreassi, and Tonelli (2016) points out that the consequences of overlapping personal and professional issues caused certain relationship problems for female entrepreneurs, leading to break down in relationships and even divorce, as a result of different convictions about work-family priorities.

There is a direct relationship between the number of hours worked and the existence of a work-family conflict, that is, the longer the hours an individual works, the more conflict there will be. However, if the work schedule is chosen by the entrepreneur, the number of conflict decreases (Bunk, Dugan, D’Agostino, \& Barnes-Farrell, 2012). In the context of entrepreneurship, the domains of family and the individual's work are more integrated, as there are greater flexibility and ease in transferring or sharing resources between the domains (Powell \& Eddleston, 2013). Hence:

\section{H3. Entrepreneurs have a lower rate of interrole conflict than non-entrepreneurs.}

One of the issues that the literature considers more relevant, which interferes in the interrole conflict, is the time available for these aspects of an individual's life - work and family (Kinnunen \& Mauno, 1998). In a survey composed of 457 entrepreneurs, Drew and Humbert (2012) found that men, on average, spend more time at work than women, with 90 per cent of men saying that they regularly work more than $40 \mathrm{~h}$ a week, against 62 per cent of women claiming to work the same amount of hours. This study reinforces the findings of other 
RAUSP

54,2

130

studies (Kinnunen \& Mauno, 1998; Parasuraman et al., 1996; Parasuraman \& Simmers, 2001) which show that when compared to women, men tend to be more involved with their work and give it more time than they give to family.

Although women are more likely than men to increase their daily work hours spent at home, especially when they have children (Drew \& Humbert, 2012; Kinnunen \& Mauno, 1998), it has been suggested that men would also like to do so but do not do it so fully (Parasuraman \& Simmers, 2001). Although the fact of owning one's own business allows for flexible schedules, entrepreneurs, especially men, give more time to their work (Drew \& Humbert, 2012; Parasuraman \& Simmers, 2001), which leads to greater interrole conflict.

Thus, the fourth hypothesis is proposed:

H4. The rate of interrole conflict among entrepreneurs is greater for men than for women.

Figure 1 summarizes the conceptual model to be tested.

\section{Method}

\subsection{Data collection}

This research is of a theoretical-empirical and quantitative type. Data were collected using an electronic questionnaire, using simple random sampling for convenience. A pre-test was conducted with ten people to see if there were any difficulties in understanding the questions. None was reported, so the questionnaires were applied and remained available online from December 10 to 28, 2014. Initially, people from the researchers' social milieu were contacted by e-mail and social media and were asked to respond to the survey. The authors then suggested that the respondents forward the questionnaires to their contacts. At the end of the collection phase, there were 156 responses, of which 55 were excluded due to missing data, yielding a total of 101 valid responses.

Entrepreneurs were defined as people owning their own businesses, as opposed to nonentrepreneurs (Van Praag \& Versloot, 2007). An initial question (Do you own your own company?) was included, which meant that the participants' responses would classify them as entrepreneurs or non-entrepreneurs.

The research tool included three commonly used questionnaires in the literature (on job satisfaction, family satisfaction and interrole conflict) which were in line with the research objectives. In all cases, a reverse translation was made from English to Portuguese and from

Figure 1.

Conceptual model
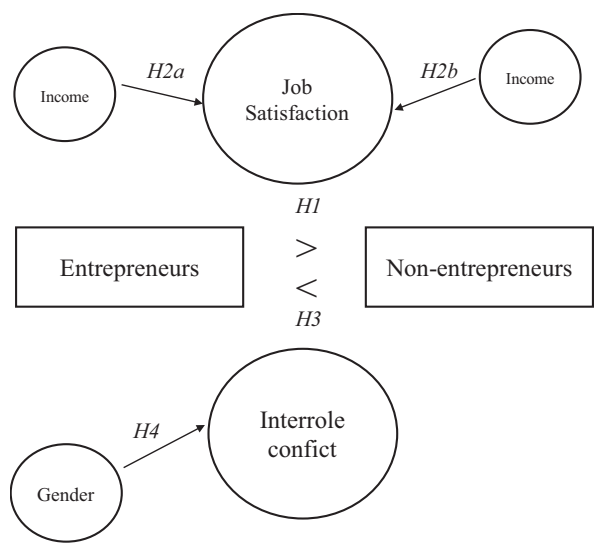
Portuguese to English, thus guaranteeing the effectiveness of the tool. The questionnaire was validated by moderators, two of whom were researchers and one a professor of entrepreneurship, thereby ensuring that it was adequate and understandable to entrepreneurs and non-entrepreneurs. The pre-test carried out with ten people also guaranteed its semantic validation.

To measure job satisfaction, the Brayfield and Rothe (1951) scale, An Index of Job Satisfaction, was used. This part of the questionnaire consisted of 18 items. The word job was translated as work (trabalho) and not as employment (emprego) to suit the entrepreneurs better. Family satisfaction was measured using the scale proposed by Carver and Jones (1992), the Family Satisfaction Scale. The scale used past tense verbs and was translated into the present to better fit the objectives of the research. This second part of the questionnaire consisted of 19 items. To measure interrole conflict, eight items referring to it in the questionnaire proposed by Kopelman, Greenhaus and Connoly (1983) were used. All items were rated with a five-point Likert scale (ranging from "strongly disagree" to "strongly agree"). Table I presents the questions given to the survey respondents.

Demographic and descriptive variables were added to the research tool to enable the hypotheses to be tested. The questions included the length of time in the activity, number of employees, activity sector, marital status, the presence of children, year of birth, schooling and income.

The 2011 Global Report classification of the Global Entrepreneurship Monitor (Kelley, Singer, \& Herrington, 2011) was used for the length of time in the activity, as shown in Table II, while for the number of employees, the SEBRAE (2013) classification was used, as shown in Table III.

\subsection{Data analysis}

To process data, a score was assigned to the items evaluated through the Likert scale, as presented in Table IV. Some questions had a negative character, that is, if the participant agreed with that item, their satisfaction rate would be reduced. Therefore, the score for these issues (marked with an asterisk in Table I) was reversed (Carver \& Jones, 1992).

For each participant, three satisfaction rates were calculated: job satisfaction, family satisfaction and interrole conflict. The rates were calculated by adding up the score in each group of questions and then dividing the result by the number of questions times two. This was done so that the measurements had values between -1 and 1 , which permitted the results to be interpreted. Lower values indicate lower levels of satisfaction.

The following procedures were used to analyse the data: descriptive analysis, correlation analysis, cluster analysis and linear regression. Of the respondents, 59 were nonentrepreneurs and 42 were entrepreneurs. In the group of entrepreneurs, 24 had children, 36 were married, 18 were male and 24 were female. Of the non-entrepreneurs, 11 respondents had children, 18 were married, 23 were male and 36 were female.

\section{Presentation of results}

A cluster analysis was first carried out, using the K-average technique, to form homogenous groups. Two groups were used (Figure 2), as the sum of squares for two groups was the largest (Belfiore, Fávero, \& Angelo, 2005). Two components were used for clustering, and they account for 77 per cent of the variability.

The Manova tests of the Pillai, Wilks, Hotelling-Lawley and Roy type were conducted to analyse the groups. Group 1 presented a mean of 0.5819 for job satisfaction, 0.7763 for family satisfaction and 0.1595 for interrole conflict. Group 2 is made up of people who are less satisfied or dissatisfied with their job, as the mean for this item was -0.1978 . The mean 


\section{RAUSP \\ 54,2}

Job satisfaction
My job is like a hobby to me
My job is usually interesting
enough to keep me from getting
bored

It seems that my friends are more

interested in their jobs*

I consider my job rather

unpleasant*

I enjoy my work more than my leisure time

I am often bored with my job*

I feel fairly well satisfied with my present job

Most of the time I have to force

myself to go to work*

I am satisfied with my job for the time being

I feel that my job is no more interesting than others I could get

I definitely don't like my job*

I feel that I am happier in my work

than most other people

Most days I am enthusiastic about my work

Each day of work seems like it will never end*

I like my job better than the

average worker does

My job is pretty uninteresting

I find real enjoyment in my work

I am disappointed that I ever took this job*
Family satisfaction Interrole conflict

In their treatment of one another, my

family was consistent and fair

I would do anything for a member of my family

I had a good time with my family

I always felt my parents supported me

I always knew what I could and couldn't "get away with" at my house

I was never sure what the rules were from day to day*

My family was the one of the least

important aspects of my life*

I would do anything necessary for any member of my family

There was too much conflict in my

family*

I usually felt safe sharing myself with my family

I was happy with my family just the way it was

Members of my family treated one another consistently

There was a great deal about my

family that I would have changed if I

could*

With my family I could rarely be myself**

I was very unhappy with my family*

I was deeply committed to my family

I often found myself feeling dissatisfied

with my family*

My family always believed in me

I found great comfort and satisfaction

in my family
My work schedule often conflicts with my family life.*

After work, I come home too tired to do some of the things I'd like to do*

On the job I have so much work to do that it takes away from my personal interests*

On the job I have so much work to do that it takes away from my personal interests*

Because my work is demanding, at times I am irritable at home* The de, hands of my Job make it difficult to be relaxed all the time at home*

My work takes up time that I'd like to spend with my family*

My job makes it difficult to be the kind of spouse or parent lid like to be*
Table I.

Instrument

Note: *Indicates the sentences that had inverted scores for the analysis

Source: Adapted from Brayfield and Rothe (1951), Carver and Jones (1992), Kopelman et al. (1983)

Age

Up to 3 months

Between 3 months and 3 years

Table II.

Over 3 and a half years
Classification

Nascent

New

Established

Source: Adapted from Kelley et al. (2011)

family satisfaction in Group 2 is lower than that in Group 1 (0.3884), and the amount of interrole conflict is higher (mean of 0.05) as the interrole conflict scale is reversed. The lower the score found, the higher the level of conflict. 
The group of those least satisfied with their job, with the family and who have greater interrole conflict is predominantly composed of employees (84 per cent), which indicates that the entrepreneurs belong to the group of those most satisfied with their job, with family and which presents less interrole conflict.

A descriptive analysis of the groups of entrepreneurs and non-entrepreneurs was carried out in an attempt to certify these results. The entrepreneurs presented a higher mean of job satisfaction (0.59) than non-entrepreneurs $(0.24)$ and a higher mean of family satisfaction $(0.72)$ than non-entrepreneurs $(0.61)$. However, the entrepreneurs presented a higher mean of interrole conflict (0.11) than employees (0.15).

Finally, linear regression models were constructed to test the hypotheses proposed in the research. The models were estimated by OLS, with $\beta 0$ representing non-entrepreneurs while $\beta 1$ is a dummy variable related to the entrepreneurs. The first model suggests the non-rejection of $H 1$, as shown in Table VI, thereby enabling one to infer that entrepreneurs are more satisfied with their job than non-entrepreneurs.

\begin{tabular}{ll}
\hline Number of employees & Size \\
\hline Up to 9 employees & Micro \\
Between 10 and 49 employees & Small \\
Between 50 and 99 employees & Average \\
Over 100 employees & Big
\end{tabular}

Source: SEBRAE (2013)

Table III.

Firms' size

\begin{tabular}{lr}
\hline Resposta & Pontuação \\
\hline Strongly Disagree & -2 \\
Partially Disagree & -1 \\
I do not agree or disagree & 0 \\
I partially agree & 1 \\
I totally agree & 2
\end{tabular}

Source: Elaborated by authors

Table IV. Answers' score

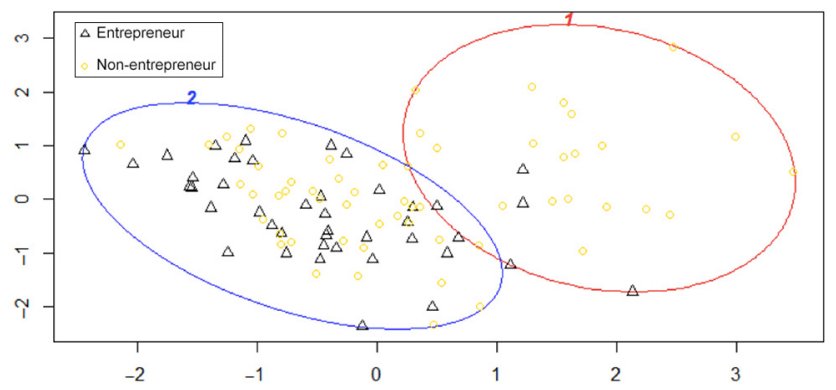

Source: Research data

Figure 2. Cluster analysis 
RAUSP

54,2

\section{4}

The second model was designed to test which variables impact the job satisfaction of entrepreneurs. The results show that the income variable alone has a (non-linear) relation with entrepreneurs' job satisfaction. This relationship is significant for individuals earning between $\mathrm{R} \$ 1,448.01$ and $\mathrm{R} \$ 2,172.00$ (Bracket 3) and between $\mathrm{R} \$ 2,172.01$ and $\mathrm{R} \$ 2,896.00$ (Bracket 4). The other income brackets did not present significant results. Thus, H2a was partially rejected.

The same analysis was conducted for the group of non-entrepreneurs. The model indicates that income alone has a significant relation with employees' job satisfaction; however, this relationship is non-linear and negative (Table VII). Non-entrepreneurs with an income range between $\mathrm{R} \$ 724.01$ and $\mathrm{R} \$ 1,448.00$ (Bracket 2) and between $\mathrm{R} \$ 2,172.01$ and $\mathrm{R}$ $\$ 2,896.00$ (Bracket 4) are less satisfied with their job than the others. Therefore, $H 2 b$ was partially rejected.

Next, the model for entrepreneurs' family satisfaction was tested. The model showed that entrepreneurs are more satisfied with family than non-entrepreneurs at a significance level of 10 per cent, as presented in Table VIII.

About interrole conflict, the models indicate that entrepreneurs present greater interrole conflict than non-entrepreneurs, but the result is not significant, as shown in Table IX

Table V.

Research results

H1. Entrepreneurs have a higher job satisfaction rate than non-entrepreneur $H 2 a$. For entrepreneurs, the job satisfaction rate varies according to income $H 2 b$. For non-entrepreneurs, the job satisfaction rate varies according to income H3. Entrepreneurs have a lower rate of interrole conflict than non-entrepreneurs H4. The rate of interrole conflict among entrepreneurs is greater for men than for women
Not rejected

Partially rejected

Partially rejected

Rejected

Rejected

Source: Elaborated by authors

\begin{tabular}{lcccc}
\hline Variables & Coefficient & Standard error & $t$-value & $\operatorname{Pr}(>|\mathrm{t}|)$ \\
\hline Intercept & 0.242 & 0.052 & 4.648 & $1.04 \mathrm{e}-5^{* * * *}$ \\
Entrepreneur & 0.353 & 0.081 & 4.375 & $3.01 \mathrm{e}-5^{* * * *}$ \\
$R^{2} \cdot 0.162$ Adjusted $R^{2} \cdot 0.1535$ & & &
\end{tabular}

Table VI.

F: 19.14 em 1 e 99 DF, $p$-value: 3.013 - -05

Entrepreneurs' job Note: Significance: 0 “****” 0.001, “***” 0.01, “*”0.05

satisfaction

Source: Research data

\begin{tabular}{lcccc}
\hline Variables & Coefficient & Standard error & $t$-value & $\operatorname{Pr}(>|\mathrm{t}|)$ \\
\hline Non-entrepreneurs & 0.446 & 0.072 & 6.193 & $-8.35 \mathrm{e}-8^{* * * *}$ \\
Income2 & -0.475 & 0.138 & -3.451 & $0.001^{* * *}$ \\
Income3 & -0.233 & 0.180 & -1.294 & 0.0201 \\
Income4 & -0.459 & 0.153 & -2.001 & $0.004^{* *}$
\end{tabular}

Table VII.

$R^{2}: 0.265$ Adjusted $R^{2}: 0.2106$

Non-entrepreneurs' Note: Significance: 0 “**** 0.001, “**” 0.01, “*” 0.05, “.” 0.1, “” 1

job satisfaction
Source: Research data 
( $p$-value $=0.6776)$. It can be inferred that there is no difference in the interrole conflict between the groups analysed herein, and that entrepreneurship is not responsible for the variation of this rate. Thus, $H 3$ is rejected.

The relationship between gender and interrole conflict was not significant $(p$-value $=$ 0.5117), which led to the rejection of $H 4$. Finally, the last model tested indicates that there is a significant relationship between family satisfaction and interrole conflict, as greater family satisfaction leads to a reduction in interrole conflict rates and vice versa. However, due to data endogeneity, it is not possible to say which variable determines the other. Table $\mathrm{V}$ summarizes the results of the hypothesis tests.

\section{Discussion of the results}

Although entrepreneurial activities are associated with risk taking, uncertainty about monthly income (Patzel \& Shepherd, 2011) and increased stress (Cardon \& Patel, 2015), the non-rejection of $H 1$ indicates that entrepreneurs are more satisfied with their jobs than non-entrepreneurs. One explanation for this result could be the fact that the advantages of being one's own boss, such as autonomy, flexibility to define working hours, independence in decision-making and ability to define work (Millan et al., 2013) are benefits which outweigh the negative points of entrepreneurship for the individuals who set up their own businesses.

It can be seen that the other variables analysed (years of company activity, number of employees, schooling, marital status and gender) neither explained entrepreneurs' job and family satisfaction nor existence of an interrole conflict, which suggests that entrepreneur satisfaction is related to aspects other than those addressed in this research. Bradley and Roberts (2004) argue that the high rates of job satisfaction among entrepreneurs could be related to aspects of their personality, such as self-efficacy, for

\begin{tabular}{lcccc}
\hline Variables & Coefficient & Standard error & $t$-value & $\operatorname{Pr}(>|\mathrm{t}|)$ \\
\hline Non-entrepreneurs & 0.677 & 0.035 & 19.208 & $<2 \mathrm{e}-16^{* * * *}$ \\
Entrepreneurs & 0.090 & 0.050 & 1.793 & 0.076 \\
Income3 & 0.204 & 0.079 & -2.578 & 0.011 \\
Income4 & -0.281 & 0.077 & -3.666 & $0.000^{* * * *}$
\end{tabular}

$R^{2}: 0.1904$, Adjusted $R^{2}: 0.1654$

$F: 7.605$ em 3 e 97 DF, $p$-value: 0.0001278

Table VIII.

Entrepreneurs' satisfaction with family

Note: Significance: 0 “**** 0.001, “**” 0.01, “*” 0.05 “.” 0.1 “” 1

Source: Research data

satisfaction

135

\begin{tabular}{|c|c|c|c|c|c|}
\hline Variables & Coefficient & Standard error & $t$-value & $\operatorname{Pr}(>|t|)$ & \\
\hline $\begin{array}{l}\text { Non-entrepreneurs } \\
\text { Entrepreneurs } \\
R^{2}: 0.001753 \text {, Adjust } \\
F: 0.1739 \text { em } 1 \text { e } 99\end{array}$ & $\begin{array}{r}0.150 \\
-0.041 \\
.00833 \\
\mathrm{e}: 0.6776\end{array}$ & $\begin{array}{l}0.063 \\
0.098\end{array}$ & $\begin{array}{r}2.371 \\
-0.417\end{array}$ & $\begin{array}{l}0.020^{*} \\
0.678\end{array}$ & \\
\hline \multicolumn{5}{|c|}{$\begin{array}{l}\text { Note: Significance: } 0 \text { “**** } 0.001 \text { “**” } 0.01 \text { * } 0.05 \text { “.” } 0.1 \text { “” } 1 \\
\text { Source: Research data }\end{array}$} & $\begin{array}{l}\text { Table IX. } \\
\text { Interrole conflict }\end{array}$ \\
\hline
\end{tabular}


RAUSP

54,2

example, while Millan et al. (2013) believe that their satisfaction is related to the autonomy, flexibility and independence provided by entrepreneurship.

The relationship between the motive which leads an individual to become an entrepreneur and job satisfaction should be investigated. Binder and Coad (2013) and Millan et al. (2013) suggest that in cases of entrepreneurship out of necessity, the rates of entrepreneurs' job satisfaction are not higher than those of employees. Factors such as self-efficacy, risk tolerance and desire for autonomy also influence the choice of entrepreneurship as a career option (Douglas \& Shepherd, 2002; Zellweger, Sieger, \& Halter, 2011). So, it is suggested that the motivation for choosing entrepreneurship should be identified in future research to see if there are differences in the quality of life of entrepreneurs which are linked to the factors which motivated their career choice.

Two factors could have influenced the results obtained in the tests of $H 2 a$ and $H 2 b$, which were partially rejected. First, assessing entrepreneurs' income is not an easy task. As it varies, it could be composed of non-taxable indexes, and, also, many entrepreneurs confuse their personal earnings with their company earnings and experience difficulties in knowing how much they actually earn (Carter, 2011). Second, many people may be reluctant to admit their real incomes in self-report surveys.

The $H 3$ test aimed to identify if entrepreneurs present higher levels of interrole conflict than non-entrepreneurs, as this is a vital factor in the quality of life of an entrepreneur, and psychologically unhealthy individuals could have difficulties in guaranteeing the success and good performance of their businesses (Nguyen \& Sawang, 2016).

One of the main causes of work-family conflict is the guilt that people feel. This sense of guilt is gender-neutral and has to do with perceptions of the roles which each gender should play and perceptions of work and family (Livingston \& Judge, 2008). These authors found that men with more traditional perceptions of gender tend to feel more guilt about family interference at work. The tool used in this paper measured the existence of an interrole conflict but not the sense of guilt related to it. In addition, Amstad, Meier, Fasel, Elfering, and Semmer (2011) emphasize the importance of analyzing factors related to the number of hours worked, such as quality of work versus the number of hours and whether the greater number of hours worked comes from a decision made by the individual or is imposed by their superiors, for example. Thus, as entrepreneurs decide to work longer hours, it may not have an impact on interrole conflict. These issues could be the cause of the rejection of $H 3$.

The fact that female entrepreneurs spend less time at work and more time with their families, and men do the opposite in spending more time at work (Drew \& Humbert, 2012), could have caused both to suffer from interrole conflict, in agreement with the rejection of $H 4$ and the results seen by Parasuraman and Simmers (2001). Perhaps, these results reflect the change that has been occurring in recent years about the role of a woman in the workplace and of a man at home. It is suggested that this result is investigated in future research.

The variation in the degree of employees' satisfaction according to their job was not evaluated. This information could show whether entrepreneurs' higher life satisfaction rates are related to their personalities or to characteristics of their jobs, such as autonomy and flexibility, which could also be experienced by employees in managerial positions, for example. It is therefore suggested that future research compare the impact of job position on employee satisfaction before comparing these data to those of the entrepreneur.

\section{Conclusion}

This research set out to identify if entrepreneurship impacts on job and family satisfaction by comparing entrepreneurs with non-entrepreneurs. The results indicate that 
entrepreneurs are more satisfied with their jobs, as was also pointed out by Binder and Coad (2013) and Van Praag and Versloot (2007).

To reach the proposed goal, a questionnaire was designed based on three consolidated scales in the literature which measure job satisfaction, family satisfaction and the existence of an interrole conflict. Cluster analysis techniques and linear regression models were used to test the hypotheses.

The results indicate non-rejection of $H 1$, thereby allowing one to infer that entrepreneurs are more satisfied with their job than non-entrepreneurs. H2, which indicates that the job satisfaction rate for entrepreneurs varies according to income, was partially rejected, as the result was only significant for certain income brackets. $H 2 b$ (the job satisfaction rate for non-entrepreneurs varies according to income) was partially rejected for the same reason.

$H 3$, predicting that entrepreneurs have a lower rate of interrole conflict than nonentrepreneurs, was rejected. Finally, $H 4$, which indicates that there is no relation between gender and interrole conflict, was rejected.

This research contributes to the literature on the impacts of entrepreneurship by addressing its impacts on the individual and not at the macro level. The results indicate that the impact of entrepreneurship on job and family satisfaction is positive, and that entrepreneurs have higher rates than non-entrepreneurs. Thus, as an academic implication, the results presented contribute to the literature by relating entrepreneurship to the quality of life and not just with financial variables, which is more common in other studies. Also, this is one of the pioneer studies on the subject using the Brazilian context, which could bring a different perspective in comparison to other countries. Potential entrepreneurs and designers of entrepreneurial stimulus programs could use the results of this article to get to know how the fact of opening one's own business could influence an individual's quality of life, job satisfaction and interrole conflict. Such knowledge is another element which could assist an individual when deciding to choose to open a company or not.

The limitations of the present research have to do with the manner in which the data were obtained, as the designation of respondents into each of the groups was not random. The responses were obtained by self-report, which could reduce their veracity (Malhotra, 2008). To analyse aspects, such as the work-family conflict, for example, it might have been interesting to identify how these relationships actually happen and not just what is reported by the respondent. This would require another type of research design. Data and analyses of respondents' income should be accepted with reservations, as individuals could feel uncomfortable about reporting their income in surveys and may even lie about it (Moore \& Welniak, 2000). Finally, the research was cross-sectional, which meant that a paired comparison between the same individuals could not be made.

As a research agenda, it is suggested that longitudinal research is carried out with the same individuals, identifying what their quality of life was like both before and after becoming entrepreneurs. This research design could be operationalized through a partnership with institutes which promote entrepreneurship and schools or universities which offer entrepreneurship courses and thus facilitate identification and access to individuals who want to be entrepreneurs. It is also suggested that individuals with a different motivation for opening their own businesses be investigated and compared, as satisfaction rates can vary for entrepreneurship out of necessity and by opportunity. Finally, comparisons between results found in various parts of Brazil and between Brazil and other countries could broaden the understanding of the subject. 
RAUSP

54,2

\section{References}

Amstad, F. T., Meier, L. L., Fasel, U., Elfering, A., \& Semmer, N. K. (2011). A meta-analysis of workfamily conflict and various outcomes with a special emphasis on cross-domain versus matchingdomain relations. Journal of Occupational Health Psychology, 16, 151-169.

Belfiore, P. P., Fávero, L. P., \& Angelo, C. F. (2005). Análise multivariada para avaliação do comportamento de grupos supermercadistas brasileiros. Administração em Diálogo, 1. Available from https://revistas.pucsp.br/index.php/rad/article/view/670

Binder, M. \& Coad, A. (2013). Life satisfaction and self-employment: A matching approach. Small Business Economics, 40, 1009-1033.

Bradley, D. E. \& Roberts, J. A. (2004). Self-employment and job satisfaction: Investigating the role of self-efficacy, depression, and seniority. Journal of Small Business Management, 42, 37-58.

Brayfield, A. H. \& Rothe, H. F. (1951). An index of job satisfaction. Journal of Applied Psychology, 35, 307-311.

Bunk, J. A., Dugan, A. G., D’Agostino, A. L., \& Barnes-Farrell, J. L. (2012). Understanding work-tofamily conflict among self-employed workers: Utilizing a cognitive appraisal framework. Journal of Entrepreneurship, 21, 223-251.

Burton, M. D., Sørensen, J. B., \& Dobrev, S. D. (2016). A career perspective on entrepreneurship. Entrepreneurship Theory and Practice, 40, 237-247.

Callanan, G. A., \& Zimmerman, M. (2016). To be or not to be an entrepreneur: Applying a normative model to career decisions. Journal of Career Development, 43, 447-461.

Cardon, M. S. \& Patel, P. C. (2015). Is stress worth it? Stress-related health and wealth trade-offs for entrepreneurs. Applied Psychology, 64, 379-420.

Carree, M. A. \& Thurik, A. R. (2010). The impact of entrepreneurship on economic growth Handbook of entrepreneurship research (pp. 557-594). Boston, MA: Springer.

Carter, S. (2011). The rewards of entrepreneurship: Exploring the incomes, wealth, and economic wellbeing of entrepreneurial households. Entrepreneurship Theory and Practice, 35, 39-55.

Carver, M. D. \& Jones, W. H. (1992). The family satisfaction scale. Social Behavior and Personality, 20, 71-84.

Dolan, P., Peasgood, T., \& White, M. (2008). Do we really know what makes us happy? A review of the economic literature on the factors associated with subjective well-being. Journal of Economic Psychology, 29, 94-122.

Douglas, E. J. \& Shepherd, D. A. (2002). Self-employment as a career choice: Attitudes, entrepreneurial intentions, and utility maximization. Entrepreneurship Theory and Practice, 26 (3), 81-90.

Drew, E. \& Humbert, A. L. (2012). 'Men have careers, women have babies': Unequal parental care among Irish entrepreneurs. Community, Work and Family, 15, 49-67.

Gartner, W. B. (1989). "Who is an entrepreneur?" is the wrong question. Entrepreneurship Theory and Practice, 13, 47-68.

Georgellis, Y. \& Yusuf, A. (2016). Is becoming self-employed a panacea for job satisfaction? Longitudinal evidence from work to self-employment transitions. Journal of Small Business Management, 54, 53-76.

Greenhaus, J. H. \& Beutell, N. J. (1985). Sources of conflict between work and family roles. Academy of Management Review, 10, 76-88. https://doi.org/10.5465/amr.1985.4277352

Guerra, G. \& Patuelli, R. (2016). The role of job satisfaction in transitions into self-employment. Entrepreneurship Theory and Practice, 40, 543-571.

Hamilton, B. H. (2000). Does entrepreneurship pay? An empirical analysis of the returns to selfemployment. Journal of Political economy, 108, 604-631.

Henderson, R. \& Robertson, M. (1999). Who wants to be an entrepreneur? Young adult attitudes to entrepreneurship as a career. Education + Training, 41, 236-245. 
Kelley, D. J., Singer, S., \& Herrington, M. (2011). Global entrepreneurship monitor 2011: Global report. Available from http://www.gemconsortium.org/docs/download/240-9

Kinnunen, U. \& Mauno, S. (1998). Antecedents and outcomes of work-family conflict among employed women and men in Finland. Human Relations, 51, 157-177.

Kopelman, R. E., Greenhaus, J. H., \& Connoly, T. F. (1983). A model of work, family and interrole conflict: A construct validation study. Organizational Behavior and Human Performance, 32, 198-215.

Lange, T. (2012). Job satisfaction and self-employment: Autonomy or personality? Small Business Economics, 38, 165-177.

Livingston, B. A. \& Judge, T. A. (2008). Emotional responses to work-family conflict: An examination of gender role orientation among working men and women. Journal of Applied Psychology, 93, 207-216. http://dx.doi.org/10.1037/0021-9010.93.1.207

Loewe, N., Araya-Castillo, L., Thieme, C., \& Batista-Foguet, J. M. (2015). Self-employment as a moderator between work and life satisfaction. Academia Revista Latinoamericana de Administración, 28, 213-226.

Malhotra, N. K. (2008). Marketing research: An applied orientation (5th ed.). Pearson Education, Londres, Reino Unido.

Millan, J. M., Hessels, J., Thurik, R., \& Aguado, R. (2013). Determinants of job satisfaction: A European comparison of self-employed and paid employees. Small Business Economics, 40, 651-670.

Mohamad, N., Lim, H.E., Yusof, N., Kassim, M., \& Abdullah, H. (2014). Estimating the choice of entrepreneurship as a career: The case of Universiti Utara Malaysia. International Journal of Business and Society, 15, 65-80. Available from https://www.researchgate.net/publication/280688343

Moore, J. C., \& Welniak, E. J. (2000). Income measurement error in surveys: A review. Journal of Official Statistics, 16, 331-361. Available from https://www.scb.se/contentassets/ca21efb41fee47d293 bbee5bf7be7fb3/income-measurement-error-in-surveys-a-review.pdf

Morris, M. H. \& Lewis, P. S. (1991). Entrepreneurship as significant factor in societal quality of life. Journal of Business Research, 23, 21-36.

Nassif, V. M. J., Andreassi, T., \& Tonelli, M. J. (2016). Critical incidents among women entrepreneurs: Personal and professional issues. Revista de Administração, 51, 212-224. http://dx.doi.org/10. 5700/rausp1235

Near, J. P., Smith, C. A., Rice, R. W., \& Hunt, R. G. (1984). Comparison of work and nonwork predictors of life satisfaction. Academy of Management Journal, 27, 184-190.

Nguyen, H. \& Sawang, S. (2016). Juggling or struggling? Work and family interface and its buffers among small business owners. Entrepreneurship Research Journal, 6, 207-246. https://doi.org/ 10.1515/erj-2014-0041

Parasuraman, S., Purohit, Y. S., DGodshalk, V. M., \& Beutell, N. J. (1996). Work and family variables, entrepreneurial career success and psychological well-being. Journal of Vocation Behavior, 48, 275-300.

Parasuraman, S. \& Simmers, C. A. (2001). Type of employment, work-family conflict and well-being: A comparative study. Journal of Organizational Behavior, 22, 551-568.

Patzel, H. \& Shepherd, D. (2011). Negative emotions of an entrepreneurial career: Self-employment and regulatory coping behaviors. Journal of Business Venturing, 26, 226-238.

Perrone, K. M., Aegisdottir, S., Webb, L. K., \& Blalock, R. H. (2006). Work-family interface: Commitment, conflict, coping and satisfaction. Journal of Career Development, 32, 286-300.

Powell, G. N. \& Eddleston, K. A. (2013). Linking family-to-business enrichment and support to entrepreneurial success: Do female and male entrepreneurs experience different outcomes? Journal of Business Venturing, 28, 261-280.

Rice, R. W., Frone, M. F., \& McFarlin, D. (1992). Work-nonwork conflict and the perceived quality of life. Journal of Organizational Behavior, 13, 155-168. 
RAUSP

54,2

Sáiz-Álvarez, J. M., Corduras Martínez, A., \& Cuervo-Arango Martínez, C. (2014). An entrepreneurial well-being model based on GEM data for Spain. International Journal of Interactive Multimedia and Artificial Intelligence, 2, 38.

Schneck, S. (2014). Why the self-employed are happier: Evidence from 25 European countries. Journal of Business Research, 67, 1043-1048.

SEBRAE. (2013). Anuário do trabalho na micro e pequena empresa: 2013 (6th ed.). Brasília, DF: DIEESE.

Shane, S. \& Venkataraman, S. (2000). The promise of entrepreneurship as a field of research. Academy of Management Review, 25, 217-226.

Strobino, M. R. D. C. \& Teixeira, R. M. (2014). Female entrepreneurship and the work-family conflict: Multicom study of the construction material trade in the city of Curitiba [Empreendedorismo feminino e o conflito trabalho-família: Estudo de multicasos no comércio de material de construção da cidade de Curitiba]. Revista de Administração, 49, 59-76.

Summers, D. (2015). The economic impact of entrepreneurship: setting realistic expectations. Academy of Entrepreneurship Journal, 21, 99-107. Available from https://www.questia.com/library/ journal/1P3-3935357531/the-economic-impact-of-entrepreneurship-setting-realistic

Thurairajah, K. (2013). Work-family conflict and its impact in career and relation to gender. European Journal of Business and Management, 5, 1-12. Available from https://www.iiste.org/Journals/ index.php/EJBM/article/viewFile/9439/9644

Van Praag, C. M. \& Versloot, P. H. (2007). What is the value of entrepreneurship? Small Business Economics, 29, 351-382.

Zellweger, T., Sieger, P., \& Halter, F. (2011). Should I stay or should I go? Career choice intentions of students with family business background. Journal of Business Venturing, 26, 521-536.

Zhao, X. R., Qu, H., \& Ghiselli, R. (2011). Examining the relationship of work-family conflict to job and life satisfaction: A case of hotel sales managers. International Journal of Hospitality Management, 30, 46-54.

Zwan, P., Hessels, J., \& Rietveld, C. A. (2018). Self-employment and satisfaction with life, work, and leisure. Journal of Economic Psychology, 64, 73-88.

Corresponding author

Luciana Padovez-Cualheta can be contacted at: lucianapadovez@outlook.com

Associate Editor: Flavio Houneaux Junior

For instructions on how to order reprints of this article, please visit our website:

www.emeraldgrouppublishing.com/licensing/reprints.htm

Or contact us for further details: permissions@emeraldinsight.com 